\title{
Influence of dietary supplementation on serum vitamin A and D concentrations and their seasonal variation in horses
}

\author{
MARKKU SAASTAMOINEN and JOHANNA JUUSELA
}

\begin{abstract}
SaAstamoinen, M. T. \& JuUSEla, J. 1992. Influence of dietary supplementation on serum vitamin $A$ and $D$ concentrations and their seasonal variation in horses. Agric. Sci. Finl. 1: 477-482. (Agric. Res. Centre of Finland, Equine Res. Sta., SF-32100 Ypäjä, Finland.)
\end{abstract}

\begin{abstract}
An experiment involving 40 adult trotters and saddle horses was conducted during a period of one year in order to investigate the influence of vitamin A (retinol) and D $(25-(\mathrm{OH}) \mathrm{D})$ supplementation on serum vitamin concentrations and the seasonal variation of the serum concentrations of these vitamins. Vitamin supplementation was started either at the beginning or in the middle of the indoor (winter) feeding period. Supplementation lasted from the beginning of September or January to the end of May. According to the results, neither the dietary vitamin supplementation nor the length of the grazing period had any consistent effect on the serum vitamin concentrations. Neither was there any systematic seasonal variation in the serum retinol and 25 -hydroxyvitamin D levels.
\end{abstract}

Key words: blood serum, equine, fat-soluble vitamins

\section{Introduction}

Fresh grass and hay are the most important sources of vitamin A (retinol) for horses (e.g., FONNESBECK and SYMONS 1967). Vitamin $D_{3}$ is synthetized in the skin (WEBB and HoLICK 1988). The synthesis of vitamin $D_{3}$ in the skin depends on season of the year, geographical latitude and intensity of sunlight (Nutrition Reviews 1989).

During the winter season the supply of fat-soluble vitamins may be inadequate. The vitamin concentrations of the most common combination of feeds used in horse feeding often decrease due to a long storage time. The synthesis of vitamin $\mathrm{D}_{3}$ in the skin during the wintertime is minor because of the short day and the small amount of sunshine.
Different chemical forms of blood vitamin A and $\mathrm{D}$ concentrations in horses have been determined in many previous studies. However, feed intake and the intake of vitamins from the basal feed have so far been poorly documented.

The aim of this study was to investigate the influence of vitamin A (retinol) and D (25-(OH)D) supplementation on the serum vitamin concentrations in horses during the different seasons of the year and the seasonal variation of serum concentrations of these vitamins. 


\section{Material and methods}

\section{Horses}

Sixteen adult half-bred saddle horses (13 geldings, 3 mares) and 24 Finnhorses (17 geldings, 5 mares, 2 stallions) were used in the trial. Of the Finnhorses, one half were trotters and the other half riding horses. The age of the horses ranged between 5 and 17 years.

The horses were exercised 1 to $2 \mathrm{~h}$ during the indoor feeding period. The trotters were trained for harness races, and the riding horses of both breeds in dressage and jumping mainly in a riding house. The half-bred saddle horses took part in regional riding competitions during the experiment. Of the Finnhorses, 7 riding horses competed in regional or national riding competitions and 8 trotters took part in national races.

During the trial the weight of the horses was recorded every two months, and the state of their health was observed regularly.

\section{Basal feeding and vitamin supplementation}

In the summer, the horses were not exercised and were kept out on the pasture. The average length of the grazing period per horse was 37 days (s.d 26).

During the indoor feeding period the the basal diet consisted of dried, timothy-dominated hay and oats. Small amounts (200-300 g) of either wheat bran or molassed sugar beet pulp were fed in addition. The diet was balanced to meet the nutritional requirements of horses engaged in moderate work, and the feeds were dosed according to exercise, body weight and body condition. The horses were also given $50 \mathrm{~g}$ per day a calcium-rich mineral mixture $(\mathrm{Ca}: \mathrm{P}=3.5: 1)$ which included supplemental vitamin $\mathrm{D}_{3}(40000 \mathrm{ky} / \mathrm{kg})$.

The horses were devided into 3 vitamin supplementation groups (10 horses in each group), while 10 horses were controls. The daily vitamin dose was given orally, by adding it to the drinking water, in the form of a ADE-vitamin solution, a different solution for each supplemented group.

The solutions were balanced for Vitamin E concentration $(60 \mathrm{mg}$ vitamin $\mathrm{E} / \mathrm{ml})$ (SAASTAMOINEN and JUUSELA 1992), and dosed individually according to the body weight (bwt) of the horse. Vitamin $A$ and $D_{3}$ concentrations in the solutions were 3750 , 2400 and $2930 \mathrm{IU}$, and 375, 240 and $293 \mathrm{IU}$ per ml, respectively. The daily supply of vitamins $A$ and $D_{3}$ in the different supplemeted groups for a horse weighing $500 \mathrm{~kg}$ was 25550 and 4800 (L1, low), 60000 and 8000 (L2, medium), and 117800 and 13500 (L3, high) IU.

Supplementation was started either at the beginning of the indoor (winter) feeding period (beginning of September) or in the middle of it (beginning of January), and it was continued to the end of May. Thus, each supplemented group was subdivided into two sub-groups according to when the supplementation had started.

Feed consumption was measured and feed samples (hay, oats, wheat bran, sugar beet pulp) were collected daily during the indoor feeding period, and the composition of the feeds was analyzed by standard methods. The $\beta$-carotene and vitamin $\mathrm{D}_{2}$ content of the samples of hay, oats and pasture grass was determined at the laboratory of Farmos Group ltd (Turku, Finland) using high performance liquid chromatography (HPLC) (SCHNEIDER 1984). The determination of the vitamin concentration in the hay and oats samples was made at the beginning and end of the indoor feeding period. The vitamin content of the grass was determined from one sample during the summer.

A detailed description of the feeds, feeding management and vitamin supplementation is given by SAASTAMOINEN and JUUSEla (1992).

\section{Blood sampling and chemical analysis}

Blood samples were taken at rest (at 8.00 a.m.) from the jugular vein into evacuated blood collection tubes. Samples were taken on the 1st of June, September, December and March, and at the end of the 
experimental period on the 31st of May. The samples were protected from light by covering the tubes with aluminium foil, and then stored at $-60^{\circ} \mathrm{C}$.

The serum vitamin A (retinol) content (ng/ml) was determined using high performance liquid chromatography (HPLC) (CATIGNONI and BIERI 1983). Vitamin D (25-OH-vitamin-D) was determined $(\mathrm{ng} / \mathrm{ml})$ by competitive protein-binding assay (PETTIFOR et al. 1976). The determinations were made in a clinical laboratory (Yhtyneet Laboratoriot Oy, Helsinki, Finland).

The coefficients of intra- and inter-assay variation were $3.4 \%$ and $5.3 \%$ for vitamin $\mathrm{A}$, and 5.0 $\%$ and $7.0 \%$ for vitamin $\mathrm{D}$, respectively.

\section{Statistical methods}

The data were subjected to an analysis of variance. The statistical methods are described in more detail by SAASTAMOINEN and JuUSEla (1992).

\section{Results and discussion}

The effect of the length of the grazing period or the dietary vitamin supplementation on the serum retinol and 25-OH-D levels (Table 1 and 2) was not found to be consistent or statistically significant $(p<0.05)$. Neither was there any consistent seasonal variation in the serum vitamin concentrations; the concentrations did not rise during the summertime.

The mean concentration of serum vitamin retinol was highest on the lowest supplementation level and lowest on the highest supplementation level (Table 1). The mean serum 25-hydroxyvitamin D concentration was also found to be highest on the lowest supplementation level (Table 2). The mean serum retinol concentration in the control horses $(\mathrm{n}=10)$ during the year's period was $148.8 \mathrm{ng} / \mathrm{ml}$ (s.d $16.3 \mathrm{ng}$ ), and their mean serum 25-hydroxyvitamin D content in the control horses was $7.05 \mathrm{ng} / \mathrm{ml}$ (s.d $0.79 \mathrm{ng}$ ). The mean concentrations for all the horses $(\mathrm{n}=40)$ were $162.2 \mathrm{ng} / \mathrm{ml}(\mathrm{s} . \mathrm{d} 22.3 \mathrm{ng})$ and $6.45 \mathrm{ng} / \mathrm{ml}$ (s.d $0.70 \mathrm{ng})$, respectively.

Table 1. Serum vitamin A concentrations ( \pm s.d.) on different sampling dates and supplemental levels when supplementation was started either in the beginning (A) or middle (B) of the indoor feeding period $(\mathrm{ng} / \mathrm{ml})(\mathrm{n}=5$ in each group).

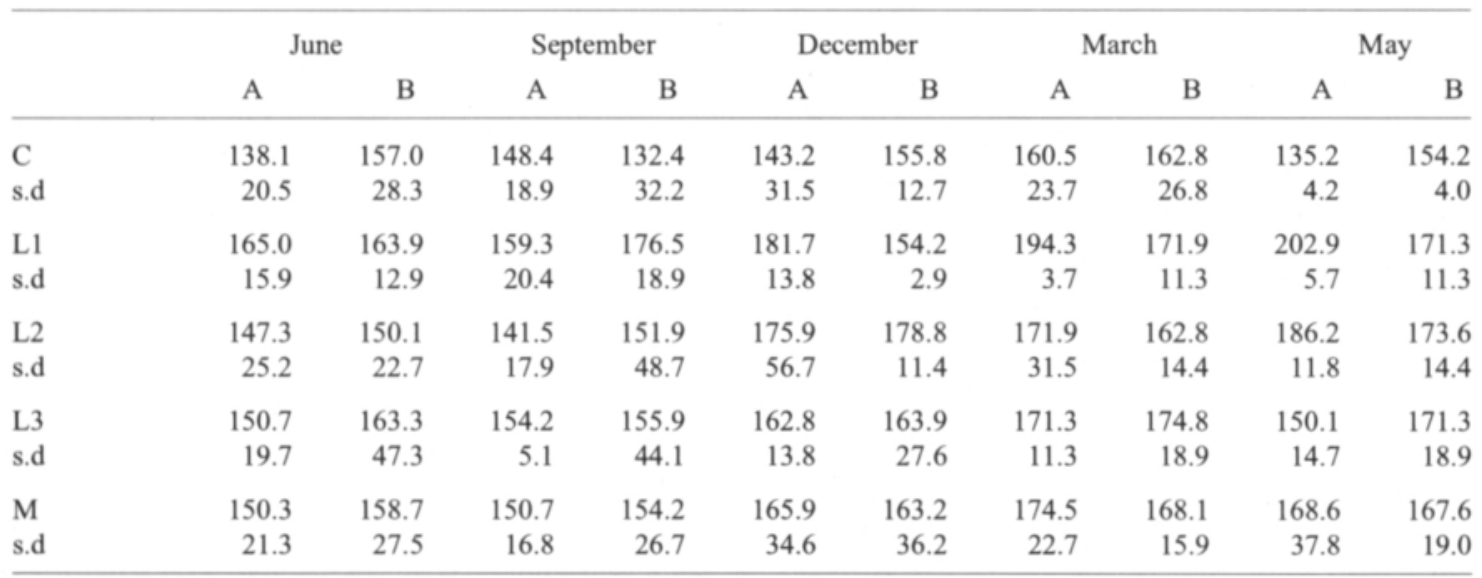

L1, L2 and L3 are the supplementation groups (low, medium, high; see Material and methods

$\mathrm{C}=$ control group; $\mathrm{M}=$ mean for all horses $(\mathrm{n}=20$ per starting group) 
Table 2. Serum vitamin D concentrations ( \pm s.d.) at different sampling dates and supplemental levels when supplementation was started either in the beginning $(A)$ or middle $(B)$ of the indoor feeding period $(\mathrm{ng} / \mathrm{ml})(\mathrm{n}=5$ in each group).

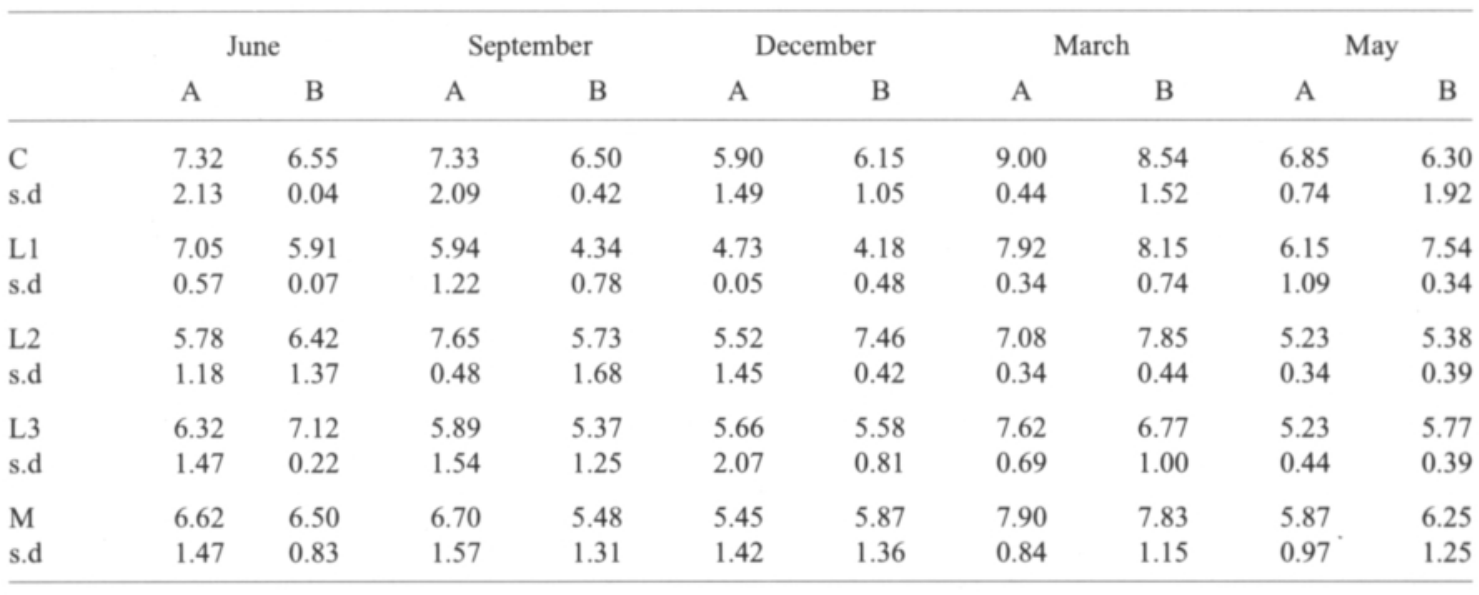

L1, L2 and L3 are the supplementation groups (low, medium, high; see Material and methdos) $\mathrm{C}=$ control group $\mathrm{M}=$ mean for all horses $(\mathrm{n}=20$ per starting group $)$

The beta-carotene content of fresh pasture grass was $300 \mathrm{mg} / \mathrm{kg}$ DM (250-350 mg; $\mathrm{n}=4)$ and that of dried hay $13.3 \mathrm{mg} / \mathrm{kg} \mathrm{DM}(5.0-20.0 \mathrm{mg} ; \mathrm{n}=4)$. These were lower than reported for good quality hay and fresh grass in Finland (SALO et al. 1982). The change in the vitamin content of the basal feeds during storage was minimal. Vitamin $\mathrm{D}_{2}$, which can be found in sun-dried roughages (McDONALD et al. 1988), was not found in measurable amounts in the hay, which had been dried mainly artifically to ensure the best hygienic quality.

The daily vitamin A intake during the grazing season could be estimated to be about $150000 \mathrm{IU}$ on the basis of the average DM intake capacity of $2 \frac{1}{2}$ $\%$ of body weight (NRC 1989). The intake of vitamin A from hay during the indoor feeding period was about $40000 \mathrm{IU}$ per day. Thus, the total daily vitamin A intake for a $500 \mathrm{~kg}$ horse was $40000 \mathrm{IU}$ in the control group and 65550, 100000 and 157800 $\mathrm{IU}$ in the various supplementation groups. The daily vitamin A supply per each $\mathrm{kg}$ of feed dry matter fed was approximately $4300 \mathrm{IU}$ for the control horses, and 7050, 10750 and $17000 \mathrm{IU}$ for the three supplemented groups. NRC (1989) recommends a vitamin A intake of $22000 \mathrm{IU} /$ day for horses $(500 \mathrm{~kg})$ engaged in moderate work, equivalent to $2140 \mathrm{IU} / \mathrm{kg}$ of feed ( $90 \%$ dry matter basis).

Since there were no measurable amounts of vitamin D in the hay, it was not possible to estimate the total vitamin D intake. However, the supplementation alone exceeded the current recommendations of NRC (1989) for daily vitamin D intake.

Probably because the intake of vitamin A from the lowest supplementation level and the basal feeds and pasture was more than adequate for adult horses as compared to NRC (1989) norms, no influence due to the supplementation and the season could be observed. Also the small data set and, the consequently high individual variation may have influenced the results.

No harmfull effects due to the high intake of vitamin A could be observed. It may be expected that the excess of vitamin A was stored in the liver (McDonald et al. 1988). 
ABrams (1979) and SKLAN and DONOGHUE (1982) have reported that blood retinol increases with increasing dietary levels. FONNESBECK and SIMONS (1967) found differences in carotene utilization by horses between different forage species. Also the base solution in the vitamin mixture has been reported to influence the utilization of vitamin A (BJONDAHL and VIRKKI 1977); the best utilization was reported for a vitamin mixture with xylitol as a base solution. In the present study mixtures with xylitol as a base solution were used.

MÄENPÄÄ et al. (1987) found seasonal variation in the blood retinol concentrations of horses in training, whereas BUTLER and BLACKMORE (1982) did not. Seasonal variation has also been found in pregnant mares and in foals (GARTON et al. 1964; MÄENPÄÄ et al. 1988a and 1988b).

The serum retinol level reported by MÄENPÄÄ et al. (1987) was $191 \mathrm{ng} / \mathrm{ml}$ in the winter and 208 $\mathrm{ng} / \mathrm{ml}$ in the summer for Finnish trotters. BUTLER and BLACKMORE (1982) have reported an average concentration of $165 \mathrm{ng} / \mathrm{ml}$ in Thoroughbreds. ABRAMS (1979) observed slightly higher concentrations, i.e., 207.4 to $241.2 \mathrm{ng} / \mathrm{ml}$ in racing Thoroughbreds. The blood retinol concentrations in brood mares have been found to range between 163 and $340 \mathrm{ng} / \mathrm{ml}$ (STOWE 1982, MÄENPÄÄ 1988a and $1988 \mathrm{~b})$. The serum retinol concentrations given in the present study are thus somewhat lower than those reported previously.

MÄENPÄÄ et al. $(1987,1988$ a) found seasonal variation also in serum 25-hydroxyvitamin D concentrations. The concentrations of 25-hydroxyvitamin D e.g. in Finnhorse mares were $4.20 \mathrm{ng} / \mathrm{ml}$ in the winter and $6.20 \mathrm{ng} / \mathrm{ml}$ in the summer (MÄEN-
PÄÄ et al. 1988a). The findings of the present study agree with those figures.

It may be suggested that blood retinol levels alone can not be used as a basis for intake recommendations of vitamin A. According to CuNCHA (1980) and MÄENPÄÄ et al. (1988 a) the blood vitamin A level is not a good indicator of the vitamin A status of the horse. However, abnormally low intakes of vitamin A have been found to produce alterations in total vitamin A concentrations in blood plasma (DONOGHUE et al. 1981).

The findings of this study further showed that the serum 25-hydroxyvitamin D concentrations did not respond the dietary vitamin $\mathrm{D}$ intake or the grazing (amount of sunshine), and, thus, cannot be considered in the determining vitamin D status and requirements of a horse. According to MÄENPÄÄ et al. (1988a), it is difficult to study the vitamin D status of horses due to the very low serum levels of 25-hydroxyvitamin D. SHORAFA et al. (1979) have reported that dietary vitamin $\mathrm{D}$ is not needed by growing ponies when sunlight is abundant.

The serum retinol and 25-hydroxyvitamin D concentrations were higher in the half-bred saddle horses than in the Finnhorses throughout the experiment $(\mathrm{p}<0.01$ to $\mathrm{p}<0.01$ for single samples). The average retinol and 25-hydroxyvitamin D concentrations during the trial were $183.5 \mathrm{ng} / \mathrm{ml}$ (s.d 16.5 $\mathrm{ng}$ ) and $6.95 \mathrm{ng} / \mathrm{ml}$ (s.d $0.70 \mathrm{ng}$ ) for half-bred saddle horses, and $147.9 \mathrm{ng} / \mathrm{ml}$ (s.d $11.6 \mathrm{ng}$ ) and $6.11 \mathrm{ng} / \mathrm{ml}$ (s.d $0.48 \mathrm{ng}$ ) for Finnhorses, respectively. No statistically significant differences were found between Finnhorse trotters and Finnhorse riding horses in the serum retinol and 25-hydroxyvitamin D concentrations.

\section{References}

ABrams, J.T. 1979. The effect of dietary vitamin A supplements on the clinical condition and track performance of race horse. Bibltcha Nutr. Dieta 27: 113-120.

BJondAHL, K. \& VIRKKI, M. 1977. Comparative studies on vitamin A utilization using three different base solutions (xylitol, polyol and water) in the ADE-vitamin solution. Nutr. Rep. Int. 15: 519-527.
Butler, P. \& Blackmore, D.J. 1982. Retinol values in the plasma of stabled thoroughbred horses in training. Vet. Rec. 111: 37-38.

Catignoni, G.L. \& Bieri, J.G. 1983. Simultaneous determination of retinol and alpha-tocopherol in serum or plasma by liquid chromatography. Clin. Chem. 29: 708-712. 
CunCha, T.J. 1980. Horse feeding and nutrition. New York. $292 \mathrm{p}$.

Donoghue, S., Kronfeld, D.S., Berkowitz, S.J. \& Cropp, R.L. 1981. Vitamin A nutrition of the equine: Growth, serum biochemistry and hematology. J. Nutr. 111: 365374 .

FonNeSBECK, P.V. \& SYMONS, L.D. 1967. Utilization of the carotene of hay by horses. J. Anim. Sci. 26: 1030-1038.

Garton, C.L., Vander, G.W. \& Fonnesbeck, P.V. 1964. Seasonal variation in carotene and vitamin A concentrations of the brood mares in New Jersey. J. Anim. Sci. 23: 1233 (Abstr.).

McDonald, P., Edwards, R.A. \& Greenhalgh, J.F.D. 1988. Animal Nutrition. 543 p.Longman. Essex.

MäenpäĀ, P., Lappeteläınen, R. \& VirkKunen, J. 1987. Serum retinol, 25-hydroxivitamin D and alpha-tocopherol of racing trotters in Finland. Equine vet. J. 19: 237 240 .

— , Koskinen, T. \& Koskinen, E. 1988 a. Serum profiles of vitamins $\mathrm{A}, \mathrm{E}$ and $\mathrm{D}$ in mares and foals during different seasons. J. Anim. Sci. 66: 1818-1423.

- , Pirhonen, A. \& Koskinen, E. 1988 b. Vitamin A, E and $\mathrm{D}$ nutrition in mares and foals during the winter season: Effect of feeding two different vitamin-mineral concentrates. J. Anim. Sci. 66: 1424-1429.

NRC 1989. Nutrient requirements of horses. Washington D.C. $100 \mathrm{p}$.

Nutrition Reviews 1989. Season, latitude, and ability of sunlight to promote synthesis of vitamin D3 in skin. Nutr. Rew. 47: 252-253.
Pettifor, J.M., Ross, F.P. \& WANG, J. A competitive proteinbinding assay for 25-hydroxyvitamin D. Clin. Sci. Mol. Med. 51: 605-607.

SaAstamoinen, M.T. \& Juusela, J. 1992. Serum vitamin E concentration of horses on different vitamin E supplementation levels. Acta Agric. Scand., Sect. A, Animal Sci., 42: (in print).

SCHNEIDER, J. 1984. Analysis of vitamin A in feeds using HPLC. In: Assays of vitamins and feed additivies. BASF Ltd, Animal Nutrition Business. p. 1-3.

Shorafa, W.M., Feaster, J.P., Ott, E.A. \& Asquith, R.L. 1979. Effect of vitamin D and sunlight on growth and bone development of young ponies. J. Anim. Sci. 48: 882-886.

Sklan, D. \& Donoghue, S. 1982. Serum and intracellular retinol transport in the equine. Br. J. Nutr. 47: 273-280.

STOWE, H.D. 1982. Vitamin A profiles of equine serum and milk. J. Anim. Sci. 54: 76-81.

WebB, A.R. \& Holick, M.F. 1988. The role of sunlight in the cutaneous production of vitamin D3. Ann. Rew. Nutr. 8: 375-399.

Manuscript received March 1992

Markku Saastamoinen

Johanna Juusela

Agricultural Research Centre of Finland

Equine Research Station

SF-32100 Ypäjä, Finland

\title{
SELOSTUS
}

\section{Ruokinnan vitamiinitäydennyksen vaikutus seerumin A- ja D-vitamiinipitoisuuksiin ja näiden vuodenaikaisvaihtelu hevosilla}

\author{
MARKKu SaASTAmoinen ja Johanna JuUSEla
}

Maatalouden tutkimuskeskus

Neljälläkymmenellä täysikasvuisella ravi- ja ratsuhevosella tutkittiin ruokinnan vitamiinitäydennyksen vaikutusta seerumin A (retinoli)- ja D $(25(\mathrm{OH}) \mathrm{D})$-vitamiinitasoihin eri vuodenaikoina. Vitamiinitäydennys aloitettiin sisäruokintakauden alussa tai keskivaiheilla. Täydennys kesti siten joko syyskuun tai tammikuun alusta toukokuun loppuun. Suun kautta annetulla vitamiinilisällä tai laidunkauden pituudella ei ollut johdonmukaista vaikutusta seerumin vitamiintasoihin. Myőskään johdonmukaista vuodenajasta johtuvaa vaihtelua seerumin A- ja D- vitamiinitasoissa ei todettu. 